\title{
Recommendations on the use of systemic treatments for urticaria and atopic dermatitis during the COVID-19 pandemic: Statement of Dermatoallergy Working Group of the Turkish Society of Dermatology
}

COVID-19 pandemisi süresince ürtiker ve atopik dermatitte sistemik tedavilerin kullanımına ilișkin öneriler: Türk Dermatoloji Derneği Dermatoallerji Çalıșma Grubu Bildirisi

๑ Andaç Salman', ๑ Sibel Alper², ๑ Nilgün Atakan³, ๑ Emel Bülbül Bașkan4, ๑ Murat Borlu5, ๑ Filiz Canpolat ${ }^{6}, \oplus$ Teoman Erdem ${ }^{7}$, ๑ Yasemin Erdem ${ }^{8}$, ๑ Ülker Gül ${ }^{9}$, ๑ Selda Pelin Kartal ${ }^{6}$, ๑ Rafet Koca ${ }^{10}$, ๑ Özlem Su Küçük ${ }^{11}$, ๑ Zerrin Öğretmen ${ }^{12}$, ๑ Esen Özkaya ${ }^{13}$, ๑ Hayriye Sarıcaoğlu ${ }^{4}, \oplus$ Ekin Șavk ${ }^{14}, \oplus$ Oktay Tașkapan ${ }^{15}, \oplus$ Serap Utaș $^{16}, \oplus$ Emek Kocatürk ${ }^{2}$

'Marmara University School of Medicine, Department of Dermatology, İstanbul, Turkey

${ }^{2}$ Koç University School of Medicine, Department of Dermatology, İstanbul, Turkey

${ }^{3}$ Hacettepe University School of Medicine, Department of Dermatology, Ankara, Turkey

${ }^{4}$ Bursa Uludağ University Faculty of Medicine, Department of Dermatology, Bursa, Turkey

${ }^{5}$ Erciyes University Faculty of Medicine, Department of Dermatology, Kayseri, Turkey ${ }^{6}$ University of Health Sciences, Dıșkapı Yıldırım Beyazıt Training and Research Hospital, Clinic of Dermatology, Ankara, Turkey ${ }^{7}$ Adatıp Sakarya Hospital, Clinic of Dermatology, Sakarya, Turkey

${ }^{8}$ University of Health Sciences, Șișli Etfal Training and Research Hospital, Clinic of Dermatology, İstanbul, Turkey 'University of Health Sciences Turkey, Hamidiye Faculty of Medicine, Department of Dermatology, İstanbul, Turkey

${ }^{10}$ Zonguldak Bülent Ecevit University Faculty of Medicine, Department of Dermatology, Zonguldak, Turkey

${ }^{11 B e z m i a l e m ~ V a k ı f ~ U n i v e r s i t y ~ F a c u l t y ~ o f ~ M e d i c i n e, ~ D e p a r t m e n t ~ o f ~ D e r m a t o l o g y, ~ I ̇ s t a n b u l, ~ T u r k e y ~}$

${ }^{12}$ Private Dermatology Clinic, Çanakkale, Turkey

${ }^{13}$ |stanbul University, İstanbul Faculty of Medicine, Department of Dermatology and Venereology, İstanbul, Turkey

${ }^{14}$ Aydın Adnan Menderes University Faculty of Medicine, Department of Dermatology, Aydın, Turkey

${ }^{15}$ Yeditepe University School of Medicine, Department of Dermatology, Istanbul, Turkey

${ }^{16}$ Acıbadem Fulya Hospital, Clinic of Dermatology, Istanbul, Turkey

Keywords: Atopic dermatitis, COVID-19, dupilumab, omalizumab, treatment, urticaria

Anahtar Kelimeler: Atopik dermatit, COVID-19, dupilumab, omalizumab, tedavi, ürtiker

Yazışma Adresi/Address for Correspondence: Andaç Salman MD, Marmara University School of Medicine, Department of Dermatology, İstanbul, Turkey Tel.: +90 5053744226 E-posta: asalmanitf@gmail.com Geliş Tarihi/Received: 22.04.2020 Kabul Tarihi/Accepted: 09.05.2020 ORCID: orcid.org/0000-0002-6407-926X

(C)Telif Hakkı 2020 Deri ve Zührevi Hastalıklar Derneği

Türkderm-Deri Hastalıkları ve Frengi Arșivi Dergisi, Galenos Yayınevi tarafından basılmıștır. 


\section{To the Editor,}

Since the first emergence of severe acute respiratory syndrome coronavirus 2 (SARS-CoV-2) associated coronavirus disease 2019 (COVID-19) in Wuhan, China in late 2019, the pathogen has spread to 210 countries/territories and finally the World Health Organization declared a pandemic in March 2020. In Turkey, the first patient with

\section{Table 1. General recommendations for patients with chronic urticaria and atopic dermatitis.}

Patients and doctors should decide on how to reduce healthcare encounters and potential exposure to COVID-19 (e.g.; remote health care such as teledermatology, increased dosing intervals between medications $)^{20}$

Strategies for coping with stress to prevent disease exacerbation

Patients should be informed on general preventive measures like social distancing and hand hygiene and skin care to prevent exacerbation or development of hand eczema

The regular home use of urticaria activity score and urticaria control test should be encouraged, the scores may be evaluated remotely by the physician (e.g. by e-mail). (patients with chronic spontaneous urticaria) an officially confirmed diagnosis of COVID-19 was reported on 11 March 2020. Since then, the total number of patients with a confirmed diagnosis has reached to 95.591 by $21^{\text {st }}$ of April, 20201

Accordingly with the changing practice in medicine throughout the world due to the measures taken to control the outbreak, the number of outpatient visits in dermatology has significantly decreased and the use of teledermatology where available is encouraged ${ }^{2}$. These unconventional clinical settings led to increased concern both in patients treated with immunomodulatory, immunosuppressive or biologic drugs and in prescribing physicians. Several reports have been published to alleviate this concern in treatment of patients with psoriasis, atopic dermatitis and pemphigus $\mathrm{s}^{3-5}$. Considering the lack of information and growing demand on the treatment of patients with common dermatoallergic conditions, a similar attempt has been made by the members of Dermatoallergy Working Group of the Turkish Society of Dermatology. In this article, The Working Group's recommendations on the use, monitoring and administration of systemic treatments for chronic spontaneous urticaria (CSU) and atopic dermatitis (AD) based on the current evidence and expert opinions will be summarized. The recommendations have been developed and decided through an

Table 2. Systemic immunomodulatory/immunosuppressive drugs used for the treatment of chronic spontaneous urticaria and atopic dermatitis

\begin{tabular}{|c|c|c|c|}
\hline Drug name & Drug class & $\begin{array}{l}\text { Mechanism of immune } \\
\text { action }\end{array}$ & Possible risk \\
\hline $\begin{array}{l}\text { Systemic } \\
\text { glucocorticoids }\end{array}$ & Steroids & $\begin{array}{l}\text { Suppression nuclear } \\
\text { factor- } \mathrm{KB}(\mathrm{NF}-\mathrm{\kappa} B) \text {, decrease } \\
\text { of transcription of pro- } \\
\text { inflammatory genes. } \\
\text { Affection of both adaptive } \\
\text { and innate immunity }\end{array}$ & $\begin{array}{l}\text { Increased risk of viral, bacterial, fungal infection, particularly at doses } \geq 20 \\
\mathrm{mg} / \text { day of prednisolon or equivalent for } \geq 2 \text { weeks } \\
\text { The CDC recommends against the use of systemic steroids during the } \\
\text { initial phase of COVID-19 due to risk of prolonged duration of viral } \\
\text { shedding }{ }^{22,23}\end{array}$ \\
\hline Cyclosporine & $\begin{array}{l}\text { Calcineurin } \\
\text { inhibitor }\end{array}$ & $\begin{array}{l}\text { Lowering the activity of } \\
\text { T-helper cells }\end{array}$ & $\begin{array}{l}\text { Risk for urinary tract infection } C S A>O M A^{24} \text { showing a } 25.4 \text { point } \\
\text { improvement during treatment }(p<0.0001) \\
\text { Higher rates of infection in higher doses }(4-5 \mathrm{mg} / \mathrm{kg} / \text { day })^{25} \\
\text { Less risk of infection compared to AZT/MMF/CS (for patients with } A D)^{26}\end{array}$ \\
\hline Azathioprine & $\begin{array}{l}\text { Antimetabolite } \\
\text { (purine analogue) }\end{array}$ & $\begin{array}{l}\text { Blockade of purine synthesis } \\
\text { and DNA replication }\end{array}$ & $\begin{array}{l}\text { Increased risk for bacterial infections. AZT/MMF/CS>MTX/CSA (for } \\
\text { patients with } A D)^{26}\end{array}$ \\
\hline $\begin{array}{l}\text { Mycophenolate } \\
\text { mofetil }\end{array}$ & Antimetabolite & $\begin{array}{l}\text { Inhibition of inosine } \\
\text { monophosphate } \\
\text { dehydrogenase and } \\
\text { nucleotide synthesis }\end{array}$ & $\begin{array}{l}\text { Increased risk for bacterial infections. AZT/MMF/CS>MTX/CSA (for } \\
\text { patients with } A D)^{26}\end{array}$ \\
\hline Methotrexate & $\begin{array}{l}\text { Antimetabolite } \\
\text { (antifolate) }\end{array}$ & $\begin{array}{l}\text { Inhibition of dihydrofolate } \\
\text { reductase and macrophage } \\
\text { activation }\end{array}$ & Less risk of infection compared to AZT/MMF/CS (for patients with AD) ${ }^{26}$ \\
\hline Dupilumab & $\begin{array}{l}\text { Monoclonal } \\
\text { antibody }\end{array}$ & $\begin{array}{l}\text { IL-4R } \alpha \text { antagonist } \\
\text { Blockade of IL-4 and IL-13, } \\
\text { decrease of Th-2 induced } \\
\text { inflammation }\end{array}$ & $\begin{array}{l}\text { Upper respiratory tract infections (in general) DUP } \leq \text { Placebo ( } 6.6 \% \text { vs } 6.4 \% \text { ) } \\
\text { Viral upper respiratory tract infections, influenza DUP < Placebo }{ }^{13} \text { including } \\
\text { skin infections and systemic infections. Immunomodulators (e.g., anti- } \\
\text { tumor necrosis factors, anti-interleukin [anti-IL]-23, anti-IL-17, Janus kinase } \\
\text { inhibitors } \\
\text { Nasopharyngitis: DUP > Placebo ( } 15.7 \% \text { vs } 13.9 \% \text { ) (not significant) } \\
\text { Urinary tract infections: DUP < Placebo ( } 2 \% \text { vs } 2.3 \% \text { ) (not significant) })^{27} \\
\text { No increased risk of serious bacterial/opportunistic infections }{ }^{26}\end{array}$ \\
\hline Omalizumab & $\begin{array}{l}\text { Monoclonal } \\
\text { antibody }\end{array}$ & $\begin{array}{l}\text { Binding to free serum IgE and } \\
\text { down-regulation of } F \subset \varepsilon R I\end{array}$ & $\begin{array}{l}\text { Meta-analysis of RCTs showed similar rates of upper respiratory tract } \\
\text { infection and nasopharyngitis in patients treated with OMA or placebo } \\
\text { Decreased disease duration and viral shedding in rhinovirus infection in } \\
\text { children with allergic asthma }\end{array}$ \\
\hline
\end{tabular}

CDC: Centers for Disease Control and Prevention, COVID-19: Coronavirus disease 2019, CSA: Cyclosporine, OMA: Omalizumab, AZT: Azathioprine, MMF: Mycophenolate mofetil, CS: corticosteroid, AD: Atopic dermatitis, MTX: Methotrexate, DUP: Dupilumab, RCT: Randomized controlled trials, IL: Interleukin 
instant messaging program (Whatsapp, Facebook Inc, USA) with the participation of the members of the Working Group. Following the determination of the subheadings, a thorough literature review has been performed. A draft manuscript was prepared in the light of the available data on the literature, clinical experiences of the experts and extensive discussions. Thereafter, a consensus was reached individually for all suggestions made by the authors and the final version of the manuscript has been formed.

Although the pathogenesis of COVID-19 has not been fully understood yet, two phases of immune responses are thought to be involved. During the early phase of the infection, the acquired immune responses are directed to eradicate the virus and halt the progression of the disease. Following the damage of the lung, however, excessive secretion of inflammatory cytokines [e.g. interferon-alpha $(\alpha)$, tumor necrosis factoralpha (TNF- $\alpha$ ), Interleukin-1 beta (IL-1 $\beta$ ), IL-6] and chemokines, also known as "cytokine storm", contributes to the development of acute respiratory distress syndrome (ARDS), the principal cause of mortality in COVID-196,7. An increased prevalence of thrombotic events has also been reported as a result of inflammation and endotheliitis ${ }^{8}$. Urticaria has also been reported among the cutaneous manifestations in $1.4 \%$

\section{Table 3. Recommendations on the use of systemic treatments for chronic sponraneous urticaria and atopic dermatitis}

\begin{tabular}{|c|c|c|c|c|c|}
\hline & Systemic glucocorticoids & $\begin{array}{l}\text { Azathioprine/ } \\
\text { cyclosporine/ } \\
\text { mycophenolate } \\
\text { mofetil/ } \\
\text { methotrexate/ }\end{array}$ & Omalizumab & Dupilumab & H1 antihistamines \\
\hline Half-life ${ }^{30-32}$ & $\begin{array}{l}\text { 2-4 hours (prednisolone) } \\
18-26 \text { hours } \\
\text { (methylprednisolone) }\end{array}$ & $\begin{array}{l}\text { Azathioprine: } 5 \text { hours } \\
\text { Cyclosporine: } 8.4 \\
\text { hours (5-18) } \\
\text { Mycophenolate } \\
\text { mofetil:16-18 hours } \\
\text { Methotrexate: } 3-10 \\
\text { hours }\end{array}$ & 26 days & $\begin{array}{l}4.8-7 \text { days } \\
\text { (in rats) } \\
11.7-20.5 \\
\text { days (in } \\
\text { monkeys) }\end{array}$ & \\
\hline Initiation of Treatment & \multicolumn{4}{|c|}{$\begin{array}{l}\text { - Should be delayed based on a benefit/risk ratio } \\
\text { - If clinical severity warrants a systemic treatment targeted biologics (dupilumab, } \\
\text { omalizumab) should be preferred to immunosuppressants } \\
\text { - If systemic corticosteroid will be used, the lowest dose and shortest duration ( } \leq 20 \\
\mathrm{mg} / \text { day of prednisolone or equivalent for } \leq 2 \text { weeks) should be planned. }\end{array}$} & \multirow{4}{*}{$\begin{array}{l}\text { - Nonsedative } \mathrm{H} 1 \text { antihistamines } \\
\text { should be preferred due } \\
\text { to their favorable safety } \\
\text { profile } 33 \text { Development and } \\
\text { Evaluation (GRADE (ie; less } \\
\text { dryness on the mucosa) } \\
\text { - Can be used, up to } 4 \text {-fold of } \\
\text { approved doses until the disease } \\
\text { control is obtained. } \\
\text { - Dosing can be adjusted by } \\
\text { the patient depending on the } \\
\text { symptom severity (UAS, UCT) }\end{array}$} \\
\hline $\begin{array}{l}\text { Ongoing treatment (no } \\
\text { infection or high risk } \\
\text { exposure) }\end{array}$ & \multicolumn{4}{|c|}{$\begin{array}{l}\text { - May be continued unless there is active infection or high-risk exposure to } \\
\text { COVID-19. } \\
\text { - Strict social isolation measures should be taken. } \\
\text { - Consider extending intervals for laboratory monitoring. } \\
\text { - Abrupt discontinuation should be avoided due to risk of exacerbation } \\
\text { - In patients with stable disease or in remission, a gradual decrease of } \\
\text { immunosuppressant dose should be considered. In case of disease exacerbation, the } \\
\text { treatment may be recommenced. } \\
\text { - In patients currently under treatment, the dosing intervals of omalizumab and } \\
\text { dupilumab may be extended in patients with stable disease in order to decrease } \\
\text { visits to healthcare units(e.g. The dose intervals might be extended up to } 8 \text { weeks } \\
\text { for omalizumab,temporary discontinuation might be considered in patients with } \\
\text { stable disease with 8-week-intervals) } \\
\text { - For omalizumab, the first three injections should be given in the hospital due } \\
\text { to small risk of anaphylaxis. Subsequent injections might be performed in small } \\
\text { healthcare units or at home, if licenced for home self-administration }{ }^{36} \\
\text { - For dupilumab, home self-administration is recommended } \\
\text { - The use of artificial tear eye drops is recommended to prevent keratoconjunctivitis } \\
\text { sicca during treatment with dupilumab. }\end{array}$} & \\
\hline $\begin{array}{l}\text { Ongoing treatment } \\
\text { (exposure to SARS- } \\
\text { CoV-2 but no } \\
\text { symptoms) }\end{array}$ & \multicolumn{2}{|c|}{$\begin{array}{l}\text { - Should be discontinued temporarily, until } \\
\text { obtaining a negative test result for COVID-19 or } \\
\text { after two weeks of symptom-free period } \\
\text { - Glucocorticoids should not be stopped abruptly, } \\
\text { tapering off is recommended }\end{array}$} & \multicolumn{2}{|c|}{$\begin{array}{l}\text { - Possibly lower risk compared } \\
\text { to immunosuppressants } \\
\text { - Tailored decision making } \\
\text { based on patients' risk factors } \\
\text { is recommended. }\end{array}$} & \\
\hline $\begin{array}{l}\text { Ongoing treatment } \\
\text { (confirmed diagnosis } \\
\text { or strong suspicion of } \\
\text { COVID-19) }\end{array}$ & \multicolumn{2}{|c|}{$\begin{array}{l}\text { - Should be stopped, regardless of COVID-19 } \\
\text { severity } \\
\text { - Glucocorticoids should not be stopped abruptly, } \\
\text { tapering is recommended }\end{array}$} & \multicolumn{2}{|c|}{$\begin{array}{l}\text { - Despite the low level of } \\
\text { evidence indicating a risk, } \\
\text { treatment might be stopped. } \\
\text { However, recent reports } \\
\text { indicate a beneficial effect } \\
\text { of dupilumab on cytokine } \\
\text { balance in COVID-1918,19. }\end{array}$} & \\
\hline
\end{tabular}

SARS-CoV-2: Severe acute respiratory syndrome coronavirus 2; COVID-19: Coronavirus disease 2019; UAS: Urticaria activity score; UCT: Urticaria control test 
of the patients with COVID-199. Risk factors for severe disease and mortality include older age (>70 years), male gender, pre-existing respiratory and cardiovascular disease (e.g. hypertension), diabetes, cancer, obesity and smoking ${ }^{10}$. On a recent analysis of risk factors and clinical manifestations of COVID-19, the authors concluded that allergic diseases are not among the risk factors for COVID-199.

Currently there is little evidence on the effect of systemic immunomodulatory, immunosuppressive or biologic drugs used in dermatology on the course of COVID-19. It might be postulated that broad suppression in multiple immune pathways caused by conventional immunosuppressives (glucocorticoids, azathioprine, cyclosporine, mycophenolate mofetil, and methotrexate) are more likely to increase the risk of infection and complications, particularly in the early stages of COVID-19 and/or in patients with aforementioned risk factors, rather than the biologics causing targeted immunosuppression ${ }^{11}$. Accordingly, the randomized controlled trials investigating the effects of omalizumab and dupilumab on CSU and AD did not show an increased risk of infection compared to placebo ${ }^{12,13}$. On the other hand, recent series from Italy did not show an increased risk for complications of SARS-CoV-2 in patients with chronic arthritis (treated with anti-TNF- $\alpha$, JAK inhibitors and low-dose methotrexate) or liver transplant compared to general population ${ }^{14,15}$. An important point is that, it is difficult to predict whether the abrupt cessation of immunosuppressive/immunomodulatory drugs and biologics would exacerbate the cytokine storm or not. For instance, IL-4, the target of dupilumab, was reported to inhibit SARS-CoV replication as a result of ACE2 downregulation ${ }^{16}$. However, recently, dupilumab was proposed as an agent that could be beneficial in severe ARDS by alleviating cytokine storm ${ }^{17}$. A recent report from Italy described two patients with AD who continued dupilumab treatment during COVID-19 and successfully recovered from the infection ${ }^{18}$. Another group from Italy recommended continuing dupilumab during COVID-19 pandemic based on the observations of elevation of Th2 cytokines in COVID-19 and fatal cases of SARS-CoV and the effect of IL-6 on polarizing Th1/ Th2 balance to the Th2 direction ${ }^{19}$.

In general, commencement of treatment with systemic immunosuppressants including biologics should be delayed based on a tailored risk/benefit analysis. However, this may not be possible in patients with severe disease activity. Ongoing treatment of urticaria and $A D$ with immunosuppressive drugs and biologics may be continued unless there is active infection or high-risk exposure to SARSCoV-2. Abrupt discontinuation of these drugs should be avoided as it may result in worsening of the disease, which may also increase the tendency to infections in patients with AD. Immunosuppressive drugs should be temporarily discontinued following the exposure to SARSCoV-2 until obtaining a negative test result for COVID-19 or two weeks of symptom-free period. In case of symptoms strongly suggesting COVID-19 or confirmed diagnosis of COVID-19, immunosuppressants should be stopped. Currently, there is no evidence to make definitive statements for patients treated with omalizumab and dupilumab, although the existing literature data regarding infectious adverse effects indicates a low-risk for these two agents. The Working Group's general statements for patients and recommendations for each treatment in different scenarios are summarized in Tables 1-3. The authors recommend to make decisions based on mutual agreement and to obtain an informed consent for each decision.

Considering the sparse literature data on the effects of these drugs on COVID-19, the recommendations should be interpreted with caution. We recommend social isolation, hand hygiene measures along with a tailored and shared decision making for each specific situation based on evidence instead of fearmongering by speculations and rumours that may hamper the treatment of patients and increase the "collateral damage" of the outbreak and hope that this document will comprise a basis for this approach.

\section{Ethics}

Informed Consent: The authors recommend to make decisions based on mutual agreement and to obtain an informed consent for each decision.

Peer-review: Externally and internally peer-reviewed.

\section{Authorship Contributions}

Concept: A.S., S.A., N.A., E.B.B., M.B., F.C., T.E., Y.E., Ü.G., S.P.K., R.K., Ö.S.K., Z.Ö., E.Ö., H.S., E.Ş., O.T., S.U., E.K., Design: A.S., S.A., N.A., E.B.B., M.B., F.C., T.E., Y.E., Ü.G., S.P.K., R.K., Ö.S.K., Z.Ö., E.Ö., H.S., E.Ş., O.T., S.U., E.K., Data Collection or Processing: A.S., N.A., Ü.G., R.K., E.Ö., E.Ş., O.T., E.K., Analysis or Interpretation: A.S., S.A., N.A., E.B.B., M.B., F.C., T.E., Y.E., Ü.G., S.P.K., R.K., Ö.S.K., Z.Ö., E.Ö., H.S., E.Ş., O.T., S.U., E.K., Literature Search: A.S., E.K., Writing: A.S., S.A., N.A., E.B.B., M.B., F.C., T.E., Y.E., Ü.G., S.P.K., R.K., Ö.S.K., Z.Ö., E.Ö., H.S., E.Ş., O.T., S.U., E.K.

Conflict of Interest: No conflict of interest was declared by the authors.

Financial Disclosure: The authors declared that this study has received no financial support.

\section{References}

1. T.C Sağlık Bakanlığı Korona Tablosu [Web Document]. URL https://covid19. saglik.gov.tr/ [accessed on 22 April 2020].

2. Villani A, Scalvenzi M, Fabbrocini G: Teledermatology: a useful tool to fight COVID-19. J Dermatolog Treat 2020;13:1.

3. Lebwohl M, Rivera-Oyola R, Murrell DF: Should biologics for psoriasis be interrupted in the era of COVID-19? J Am Acad Dermatol 2020;82:1217-8.

4. Wollenberg A, Flohr C, Simon D, et al: European Task Force on Atopic Dermatitis (ETFAD) statement on severe acute respiratory syndrome coronavirus 2 (SARS-Cov-2)-infection and atopic dermatitis. I Eur Acad Dermatol Venereol 2020

5. Shakshouk H, Daneshpazhooh M, Murrell DF, Lehman JS: Treatment considerations for patients with pemphigus during the COVID-19 pandemic. J Am Acad Dermatol 2020.

6. Li X, Geng M, Peng Y, Meng L, Lu S: Molecular immune pathogenesis and diagnosis of COVID-19. J Pharm Anal 2020;10:102-8.

7. Shi $Y$, Wang $Y$, Shao $C$, et al: COVID-19 infection: the perspectives on immune responses. Cell Death Differ 2020;27:1451-4.

8. Bikdeli B, Madhavan MV, Jimenez D, et al: COVID-19 and Thrombotic or Thromboembolic Disease: Implications for Prevention, Antithrombotic Therapy, and Follow-up. J Am Coll Cardiol 2020.

9. Zhang J, Dong $X, C$ ao $Y$, et al: Clinical characteristics of 140 patients infected with SARS-CoV-2 in Wuhan, China. Allergy 2020.

10. Jordan RE, Adab P, Cheng KK: Covid-19: risk factors for severe disease and death. BMJ 2020;368:m1198.

11. Price KN, Frew JW, Hsiao JL, Shi VY: COVID-19 and Immunomodulator/ Immunosuppressant Use in Dermatology. I Am Acad Dermatol 2020;82:e173-e5 
12. Zhao ZT, Ji CM, Yu WJ, et al: Omalizumab for the treatment of chronic spontaneous urticaria: A meta-analysis of randomized clinical trials. J Allergy Clin Immunol 2016;137:1742-50.e4.

13. Eichenfield LF, Bieber T, Beck LA, et al: Infections in Dupilumab Clinical Trials in Atopic Dermatitis: A Comprehensive Pooled Analysis. Am J Clin Dermatol 2019;20:443-56

14. Monti S, Balduzzi S, Delvino P, Bellis E, Quadrelli VS, Montecucco C: Clinical course of COVID-19 in a series of patients with chronic arthritis treated with immunosuppressive targeted therapies. Ann Rheum Dis 2020;79:667-8.

15. D'Antiga L: Coronaviruses and immunosuppressed patients. The facts during the third epidemic. Liver Transplant 2020.

16. de Lang A, Osterhaus ADM, Haagmans BL: Interferon- $\gamma$ and interleukin-4 downregulate expression of the SARS coronavirus receptor ACE2 in Vero E6 cells. Virology 2006;353:474-81.

17. Storm C, Hawill B, Geraci J: Repurposing Dupilumab May Treat Advanced COVID-19 Patients With Severe Acute Respiratory Syndrome By Mitigating. (Preprint) (https://www.researchgate.net/publication/340084903 Repurposing_Dupilumab_May_Treat_Advanced_COVID-19_Pa-_tients_ With_Severe_Acute_Respi-_ratory_Syndrome_By_Mitigating_Cytokine_ Storm.) [accessed on 23 April 2020].

18. Ferrucci S, Romagnuolo M, Angileri L, Berti E, Tavecchio S: Safety of dupilumab in severe atopic dermatitis and infection of Covid-19: two case reports. J Eur Acad Dermatol Venereol 2020.

19. Patruno C, Stingeni L, Fabbrocini G, Hansel K, Napolitano M: Dupilumab and COVID-19: what should we expect? Dermatol Ther 2020.

20. Pathoulas JT, Stoff BK, Lee KC, Farah R: Ethical outpatient dermatology care during the coronavirus (COVID-19) pandemic. J Am Acad Dermatol 2020;82:1272-3.

21. Caplan A, Fett N, Rosenbach M, Werth VP, Micheletti RG: Prevention and management of glucocorticoid-induced side effects: A comprehensive review: Infectious complications and vaccination recommendations. J Am Acad Dermatol 2017;76:191-8.

22. Russell CD, Millar JE, Baillie JK: Clinical evidence does not support corticosteroid treatment for 2019-nCoV lung injury. Lancet 2020;395:473-5.

23. Management of Patients with Confirmed 2019-nCoV | CDC [Web Document]. URL https://www.cdc.gov/coronavirus/2019-ncov/hcp/clinicalguidance-management-patients.html [accessed on 19 April 2020].

24. Savic S, Marsland A, McKay D, et al: Retrospective case note review of chronic spontaneous urticaria outcomes and adverse effects in patients treated with omalizumab or ciclosporin in UK secondary care. Allergy, Asthma Clin Immunol 2015;11:21.

25. Kulthanan K, Chaweekulrat P, Komoltri C, et al: Cyclosporine for Chronic Spontaneous Urticaria: A Meta-Analysis and Systematic Review. J Allergy Clin Immunol Pract 2018;6:586-99.

26. Schneeweiss MC, Perez-Chada L, Merola JF: Comparative Safety of Systemic Immuno-modulatory Medications in Adults with Atopic Dermatitis. J Am Acad Dermatol 2019;31:S0190-9622.

27. Ou Z, Chen C, Chen A, Yang Y, Zhou W: Adverse events of Dupilumab in adults with moderate-to-severe atopic dermatitis: A meta-analysis. Int Immunopharmacol 2018;54:303-10.

28. Zhao ZT, Ji CM, Yu WJ, et al: Omalizumab for the treatment of chronic spontaneous urticaria: A meta-analysis of randomized clinical trials. J Allergy Clin Immunol 2016;137:1742-50e4.

29. Esquivel A, Busse WW, Calatroni $A$, et al: Effects of Omalizumab on Rhinovirus Infections, Illnesses, and exacerbations of asthma. Am J Respir Crit Care Med 2017;196:985-92.

30. Bressan AL, Silva RS da, Fontenelle E, Gripp AC: Immunosuppressive agents in Dermatology. An Bras Dermatol 2010;85:9-22.

31. XOLAIR® Omalizumab For Subcutaneous Use [Web Document]. URL https:// www.accessdata.fda.gov/drugsatfda_docs/label/2003/omalgen062003LB. pdf [accessed on 23 April 2020].

32. EMA Dupixent Assessment report [Web Document] URL https://www. ema.europa.eu/en/documents/assessment-report/dupixent-epar-publicassessment-report_en.pdf [accessed on 23 April 2020].

33. Zuberbier $T$, Aberer $W$, Asero $R$, et al: The EAACI/GA2LEN/EDF/WAO Guideline for the Definition, Classification, Diagnosis and Management of Urticaria. Allergy 2018;73:1393-1414.

34. Liu H, Farley JM: Effects of first and second generation antihistamines on muscarinic induced mucus gland cell ion transport. BMC Pharmacol 2005;5:8.

35. Niemeyer-van der Kolk T, van Maaren MS, van Doorn MBA: Personalized omalizumab treatment improves clinical benefit in patients with chronic spontaneous urticaria. J Allergy Clin Immunol 2018;142:1992-4.

36. Denman S, Ford K, Toolan J, et al: Home self-administration of omalizumab for chronic spontaneous urticaria. Br J Dermatol 2016;175:1405-7. 